\title{
Mystical Experience and the Emergence of Creativity
}

\author{
By ANTOON GEELS
}

\section{Introduction}

\subsection{Two current problems within mystic research}

Since the turn of the century, mystic researchers have pointed to the similarities between mystics on the one hand, and artists, poets, mathematicians, musicians, in short, all those who are involved in creative activity. One common denominator, using the terminology of the day, is a state of inspiration, a sort of creative ecstasy, an immediate insight of some form. However, the question of what psychological processes can activate "inspiration" seemed to be unanswerable. According to Evelyn Underhill (1926) it probably arises from the unconscious, where the best and the worst sides of man, "the most savage and most spiritual parts of the character", are located (62f). Every intuitive person is endowed with a "flexible threshold"' to enormous unconscious powers, which can turn him into a genius, a madman or a saint. The mystics themselves, as well as Evelyn Underhill, assume that these creative resources, which the Sufis call "the Constructive Spirit" and the Cabalists "Yesod", lie beyond the world perceived by our senses. The mystic "has a genius for transcendental ... discovery in exactly the same way as his cousins, the born musician and poet, have a genius for musical and poetic discovery. In all three cases, the emergence of these higher powers is mysterious, and not least so to those who experience it" ( $74 \mathrm{ff})$. In a later work $(1920,67 \mathrm{ff})$ Underhill uses other psychological language. Of artists, musicians, philosophers and physicists, she writes that "the twin powers of a steadfast, selective attention and of creative imagination are at work". The creative imagination is expressed in suggestive language, abounding in metaphors and pictures, which makes it possible for others to appreciate to a certain extent the special experiences of the mystic.

A similar view of the relationship between profane and religious creativity is held by James H. Leuba, the author of a classic within the psychology of religion, The Psychology of Religious Mysticism, published in 1925. In a chapter on "scientific inspiration or revelation" Leuba states that the word inspiration says something of the suddenness and unexpectedness of the 
creative process: "both in the field of imagination and of rational construction, there come, after periods of mental striving or vague brooding, fructifying moments, effortless and unexpected, which give the impression of inspiration" (243). Mystics, scientists and artists have this process in common. But while Underhill works mainly with the great geniuses and the classic mystics, Leuba extends this process to a daily phenomenon, albeit on a lower level of intensity. "All kinds of ideas, and ideas of all degrees of puerility and importance, appear in our minds under the conditions which we have found to be those of revelation." These revelations represent for Leuba "gifts from unknown sources" (244).

In a Swedish context, the concept of inspiration is most often linked with Tor Andrae, who in his work Mystikens Psykologi (the Psychology of Mysticism) from 1926 wrote "that the religious inspiration in many respects is so strongly reminiscent of the artistic, that they both can be said to constitute to a certain extent the same psychic phenomenon ..., that their initial forms coincide" (581f). The same view, that is, that there are basic similarities between mystics and scientists or artists, is found in a more recent work on mystic experience by Ben-Ami Scharfstein. By presenting examples from authors, physicists and artists, Scharfstein tries to show, among other things, that all strive to create unity, be it externally in the outer world, or internally within man himself (1973, 71-98). However, Scharfstein shows no greater interest in the psychological process which is possibly relevant to the discussion in this context.

The first problem I wish to discuss here is whether there exists a common model for understanding the similarities which many researchers have hinted at, between religious and profane creativity. This question is intimately linked with another extremely central but little discussed problem within mystic research: with which psychological concepts should one describe the special knowledge and experiences which mystics say they have? What the majority of researchers agree upon is that it appears to be another type knowledge than discursive thinking. A quick glance at a couple of common definitions of mysticism is enough to make the problem clear. The psychologist of religion Walter $\mathrm{H}$. Clark defines mysticism as "the subjective experience of a person who has what he tells others is a direct apprehension of some cosmic Power or Force greater than himself ... The experience is intuitive rather than sensuous or rational (1969, 263) '. In the previously mentioned classic in the psychology of religion by Leuba, we find that mysticism is "any experience taken by the experiencer to be a contact (not through the senses, but 'immediate', 'intuitive') or union of the self with a larger-than-self be it called the World-Spirit, God, the Absolute, or otherwise" $(1972,1)$. In an oft quoted classic from the 
20's, James B. Pratt $(1926,337)$ writes that mysticism is "the sense of the presence of a being or reality through other means than the ordinary perceptive processes or the reason ... It is ... an immediate and intuitive experience." The philosopher of religion, Robert M. Gimello, states that the mystic experience is characterized, among other things, by " a cessation of normal intellectual operation (e.g. deduction, discrimination, ratiocination, speculation, etc.) or the substitution for them of some 'higher' or qualitatively different mode of intellect (e.g. intuition)" (1978, 178). To show that the situation has not changed markedly as regards the difficulty of making deeper psychological analyses of the intensive experiences of mystics and other creative persons, I will quote from a newly written work by Robert S. Ellwood Jr. There the mystic experience is defined as "experience in a religious context that is immediately or subsequently interpreted by the experiencer as an encounter with ultimate divine reality in a direct nonrational way that engenders a deep sense of unity and of living during the experience on a level of being other than the ordinary' (the italics are mine). In an explanatory comment to this definition Ellwood writes that the concept of direct and non-rational means that normal perception is suspended wholly or partially and that the perception of time is disturbed. These symptoms indicate, says Ellwood, that the individual "sees the object of the experience with some nonsensory organ of perception" (1980, $29 \mathrm{ff}$ ). What this organ might be he does not suggest.

All the researchers quoted above believe that the experience of the suprahuman cannot occur via "ordinary perceptive processes", via the senses, but only immediately, intuitively. It therefore seems clear that mystic research, if it is to progress, is in need of a model for different (un)conscious perceptual and cognitive processes including insight into how they are activated. It is just such a model that I intend to present here.

This presentation of the problem makes it clear that my starting point is a "general systems approach", an approach perhaps most propagated by Ludwig von Bertalanffy, who defines systems as "complexes of elements standing in interaction". The methodological problem is to formulate problems of a general type. One consequence of "general systems" is "the appearance of structural similarities or isomorphisms in different fields" (von Bertalanffy 1969, 32f). It is my intention in this article to search tentatively for such isomorphisms within the areas of mysticism and creativity.

The common theoretical base for the areas of mysticism and creativity is, as stated earlier, a model for perceptual and cognitive development. I thus build on the American psychiatrist Silvano Arieti, whose research on schizophrenia and creativity has received a great deal of attention. After 
this presentation it is natural for a psychologist of religion to ask what are the religious techniques or exercises that can activate such processes. This question is dealt with in the third section of this article. In the fourth section the model's significance for other central problems within mystic research is discussed, for example, the question of whether is is possible to utilize typologies for mystic experience and the relationship between experience and interpretation. In the last section I return to the relationship between mysticism and creativity, and especially to the important question of how the hypothetical constructs can be operationalized and become the object of scientific research.

\section{The Intrapsychic Processes}

\subsection{Silvano Arieti-a model for perceptual and cognitive development}

It is perhaps unnecessary to mention that Silvano Arieti proceeds from the same "systems approach" that we mentioned earlier. Apart from his highly regarded studies of schizophrenia, he has throughout his research career shown an interest in creativity research and searched for isomorphisms within both areas of study. The results of nearly three decades of research and clinical experience are presented in the great volumes Interpretation of Schizophrenia (1974) and Creativity, the Magic Synthesis (1976). It is the latter work which provides the foundation for the following presentation.

Arieti also calls his method a "psychostructual approach", which means that with the aid of depth psychology, he searches for structures and the systems on which those structures lie. An important base for his model is the developmental psychologist Heinz Werner, who has the same theoretical viewpoint (see Bertalanffy 1969, $193 \mathrm{ff}$ ). Arieti writes that Werner is one of the two authors who have influenced him most $(1976 a, 7)$. The other is Jean Piaget, whose unprecedentedly influential developmental psychology had very much in common with Werner's (Langer and Sugarman, 1978). What both Werner and Piaget lack, according to Arieti, is the integration of the human cognition into a psychodynamic entirety. In Werner's developmental psychology, too little consideration is given to concepts such as the unconscious, motivation and primary process, an unconscious level in the human personality structure where logical and formal relations are not thought to exist. And Piaget describes an increasingly mature adaption to the surrounding reality, but remains on the level of secondary process, that is, logic, reason and knowledge of the external reality. His results are not related to psychopathology or creativity (1976 $a$, viii, $7 \mathrm{f}$ ). These relations in particular are important for this study. When, as we have seen, a number of 
studies point to the similarities between intensive religious experiences, psychopathological states and creativity, it is then that we need an integrated view of man's cognitive development which also takes psychodynamic factors into consideration. The relationship to psychopathology, however, will only be touched upon in this article.

Before we get further into Arieti's model of human perceptual and cognitive development, I would like to mention a few of his more general viewpoints. According to Werner, development implies an increasing degree of differentiation in a hierarchic structure. Through repetition and learning the child acquires increasing access to a differentiated cognitive structure with which ingoing stimuli are handled and interpreted. As the logical and abstract thinking processes take over, the more primitive cognitive processes are relegated to subconscious and preconscious levels. These more primitive levels nevertheless exist within the human organism as a resource. In certain psychopathological states and even in the creative process, these repressed cognitive processes can be activated. It is characteristic of man's psychological structure, Arieti states, "to use all the levels of activity, whether in succession, in a given sequence, or in simultaneous action"' (1976, 51). According to the psychoanalyst Lawrence Kubie (1958) man can be placed upon a scale according to the extent to which pre- or subconscious processes are allowed to influence consciousness. An all too firm foothold in external reality with little access to other processes is a state just as fixated as one characterised by a domination of the pre- and subconscious, as exhibited by schizophrenic patients. Somewhere in the middle of this scale we find the artist, scientist and, we might add, certain mystics.

Arieti divides the distinct cognitive processes of the human psyche into three main categories: the primary process, which dominates in dreams and in certain states of mental illness; the secondary process, that is, a normal waking consciousness which follows the laws of reality-oriented logic; and the tertiary process, a term which Arieti suggests to cover the "magic synthesis" of primary and secondary processes, the springboard of creativity. He admits here his dependence upon Freud, but at the same time notes that the tertiary process does not exist in classic Freudian analysis. Freud was interested in primary process not so much as structures but rather as abnormal phenomena or as bearers of subconscious motivations. Arieti, however, suggests the following for the creative process: "Instead of rejecting the primitive (or whatever is archaic, obsolete, or off the beaten path), the creative mind integrates it with normal logical processes in what seems a 'magic' synthesis from which the new, the unexpected, and the desirable emerge"' $(1976,13)$. 
In his discussion of creativity's psychological components, Arieti first looks at the primitive perception, a complex process of whose last phase we become conscious. Experimental research has shown that we first learn to perceive parts, which are eventually welded into units. A three month old child first sees its mother's forehead, eyes and nose, and later the whole mother. Blind people who have regained their sight must first acquaint themselves with the various parts of an object before the parts can build a whole. In certain states of neurological illness the reverse is possible: perception disintegrates, one perceives only fragments of the whole. The phenomenon is called dedifferentiation $(1976,39 \mathrm{ff})$. The necessary prestages of conscious perception, gestalt-free perception, partial perception and perception of obvious parts, are repressed. The reason for this is that we cannot provide them with meaning $(1976,194 \mathrm{f} ; 1974,280 \mathrm{ff}$. See even Schachtel 1959; Goleman 1981).

As opposed to perception, images are purely mental phenomena which are built upon the memories of earlier perceptions. The production of images belongs to the level of the primary process. It is the most primitive form of symbolic functioning. After approximately seven months a child is at the point where it can produce and experience images. From that point on, images are an important part of the inner reality. They occur spontaneously, but appear more easily when the individual is passive, and when external stimuli are reduced. Rest, isolation and meditation aid the production of images (1976, 46).

The most common images are of either the visual or the auditive type. The eidetic images are a special type and are experienced mainly by children. As opposed to other types, eidetic images are most reminiscent of photographic reproductions of earlier perceived objects. But otherwise, images are relatively blurred and defective reproductions of earlier perceptions. Arieti states that this is of considerable importance for the creative process, as the discrepancy between the original perception and its image introduces what is new; it is the seed of creativity. "Imagery thus emerges not only as the first or most primitive process of reproducing or substituting for the real, but also as the first or most primitive process of creating the unreal' $(1976,49)$. Its function is to deal with that which is absent in two senses: the absence of, for example, a friend or food; the absence of that which does not exist and must therefore be created. The production of images does not necessarily only indicate wish-fulfilment (classical analysis) but also implies that the individual has not passively adapted to reality.

Thinking in images can even become a goal in itself. At this point it can lead to daydreaming and in more extreme cases to adualism, that is, the inability to differentiate between the inner and outer world. In other cases, 
psychedelic drugs like mescaline or LSD-25 are utilized in order to experience primitive or intensive images.

A final note of importance for this section is that images are often represssed. The result can be frustration. One way of avoiding this is to externalize the images, through the activation of various psychic levels and diverse transformatory mechanisms $(1976,44 \mathrm{ff})$.

The next level is called amorphous cognition, a type of cognition lacking concepts, that is, lacking forms of expression such as pictures, words, thoughts or actions. Since this concerns a purely inner process, Arieti has called this function endocept ${ }^{1}$ (from the Greek. endo, within) to differentiate it from concept, a more mature type of communication. Other researchers use concepts like non-verbal, subconscious or preconscious cognition when referring to the endocept.

The German Würzburg school were among the first to draw attention to experiences such as surprise, apprehension, doubt, which lie on a preverbal level. Some individuals have greater access to endoceptual experiences than others. This brings us back to Kubie, who stated that there are great differences in individual contacts with pre- and subconscious processes. Similarly, Arieti also maintains that the endocept is largely repressed in adult human life. When it appears, the individual is well aware of the discrepancy between the endocept and verbal explanations. At that point one may hear the comment "I know what I mean and feel, but I just can't describe it." The endocept also plays an important role in situations of intense emotional content, for example, "intense artistic appreciation". Arieti sees empathy as a form of communication which is built to a large extent upon a primitive understanding of each others endocept. A typical example of this is the relationship between mother and child (1976, 56ff).

What Arieti wishes to emphasize is that a large part of man's cognitive activity occurs in a non-conceptual, endocept state. The source of this amorphic activity is twofold: a primitive level, for example, an extended image or other non-differentiated mental activity; the contents of higher mental levels which avoid consciousness and return to more primitive levels. One discovers time and again, says Arieti, that "the psyche functions in two ways, from a low level to a high and from a high level to a low" (1976, $53 \mathrm{ff})$.

The endocept tends to be the object of various transformations. This is an important point for the understanding of inexpressible, intensive exper-

1 Arieti comments: "At the present state of
knowledge, we cannot obtain certain proof of
the existence of the endocept. It remains the
least clear and the least scientifically verifi-

3-Religious Ecstasy able of the ideas presented in this book ... However ... there is some evidence for its existence, both from logical inference and from clinical observation" $(1976,55)$. 
iences. The following possibilities of transformation are mentioned: "1, into communicable symbols, that is, into various preconceptual and conceptual forms (the symbols are generally words but may also be drawings, numbers, sounds and so forth); 2 , into actions; 3 , into more definite feelings; 4 , into images; and 5 , into dreams, fantasies, daydreams, reveries, and so forth. In all these cases they may constitute the springboard to creativity" $(1976,60)$.

A higher stage in the creative process is called primitive cognition or paleological thinking, which belongs to the thinking of the primary process. This immature thought form occurs in dreams, among other things, and in certain mental illnesses, above all, schizophrenia. It can arise spontaneously in otherwise healthy individuals who have been overwhelmed by emotions, for example, prejudice, or anger. These primitive thought processes are the main subjects of Arieti's research (Special note 1974, ch. 16).

While images and endocepts are found in all people, paleological thinking occurs only minimally for the average person. In its purest form it is studied in schizophrenic patients $(1976,66 \mathrm{f})$. Paleological thinking has three characteristics: identification based upon similarity, altered relation between word and meaning, concretization and perceptualization of the concept.

Identification based upon similarity is built upon a logic which deviates from common Aristotelian logic. The principle is that one finds at least one common element for two or more things or people, which is sufficent for identification. An example is the patient who asserted that she was the Virgin Mary. When asked why she believed this, she answered: "I am a virgin. The Virgin Mary was a virgin; I am the Virgin Mary". Since the predicates of a subject are innumerable it is impossible to predict what type of identification will take place.

A constructive variation of identification based upon similarity is scientific discoveries. There are innumerable examples of scientists who have seen similarities between things which were previously viewed as quite different. After having studied a mathematical problem for 14 days, the Frenchman Henri Poincaré stepped onto the bus and suddenly, with "immediate wisdom", gained an insight into the similarity between two mathematical Titans which had not been seen before. The discovery led to a breakthrough in mathematics. Isaac Newton noticed the common quality in the apple which falls to the ground and the gravitational attraction of the planets. The result was the law of gravitation. In Arieti's terms, this is a question of the coupling of the primary process to concepts, that is, the secondary process. Out of this constructive combination the tertiary process arises, the creative product (1976, $270 \mathrm{ff}$ ). This type of thinking is also the foundation of Freudian symbolism. The common predicate for the 
words pen and penis is their long extended form, and for a box and a vagina is that they both can contain something. The same type of thinking is found in children between the ages of $1 \frac{1}{2}$ and $3 \frac{1}{2}$ years. All adults are called mamma or pappa because they have the element in common of being adults. Finally, Arieti shows that paleological thinking is very common among primitive peoples, although he does not attach any value or evolutionary significance to this $(1976,68 \mathrm{ff})$.

In an effort to return quickly to what was said at the start of this section, we may notice a fairly recent experimental study by G. Smith and A. Danielsson. The authors showed that the capacity for "symbolic functioning' is a common element in both children and creative adults, that is, they have a greater ability "to perceive several meanings behind a correctly perceived object"' $(1979,5)$. Noncreative people tend to maintain one single interpretation. In order to be creative, regardless of the subject area, the individual must be able to go beyond the conventional interpretations of reality. The symbolic function can serve as a starting place for creativity. The author's operational definition of creativity is "an individual's ability or inclination to transgress the confines of an established (conventional) perceptual context" $(1979,1)$. This definition can be compared with what Joachim Israel has written about the phenomenon of transgressing. "It is a process through which we actively exceed or transgress the existing boundaries of our knowledge, including our problematized knowledge" (Israel 1980, 56). An example is the chess player, who must be able to exceed known combinations in order to become a chess master. Transgressing is the source of creativity (Israel 1980,60).

The other characteristic of paleological thinking is that the relationship between a word and its meaning content can change. One can refer to a table, for example, through three different aspects: the table's connotation, its definition; its denotation, the table as a physical entity; and its verbalization, the sound of the word itself. A healthy person in a waking state is most concerned about the table's connotation and denotation. He can also vary his attention between the three aspects. When an individual thinks paleologically, he connotates differently and focuses on the denotation and verbalization at the expense of the connotation. As far as the first change is concerned, words no longer represent classes or groups but rather specific personifications of the same. The word "dog" for example, is not used in relation to all members of a specific species, but rather for "the dog sitting on the corner over there",

The third characteristic is that a concept can be concretized and even perceptualized. In the psychic process which results in a schizophrenic transformation of an individual's personality, concretizing and perceptua- 
lizing occur during the fourth and last phase. "Active concretization means that the psyche is still capable of conceiving the abstract but not of sustaining it, because the abstract is too anxiety-provoking or disintegrating. Abstract ideations are thus immediately transformed into concrete representations". In this respect the artist, poet, and the schizophrenic have something in common. All transform abstract concepts into perceptual images or pictures. However, in contrast to the schizophrenic, the artist maintains contact with the abstract plane (Arieti 1976a, 272; 1974, 218f).

The perceptualization of concepts is an extention of the concretizing process. There are many different levels of this phenomenon. A normal perceptualizing process occurs during dreams. An abnormal form of this process is seen, in its fullest expression, in the hallucinatory experiences of the schizophrenic patient. The perceptualization of concepts is the hallucination's most specific characteristic (1974, 266ff). Paleological thinking tends to build concrete conceptions of what in normal thinking occurs in abstract form. This is common for schizophrenic patients, for whom indefinite feelings become definite, the invisible becomes visible, etc. (1976, 82 f).

Arieti places religious hallucinations among the non-schizophrenic hallucinations, such as those that occur, for example, in a state of panic, or because of organic disturbances in the central nervous system, delirium tremens etc. However, those with religious hallucinations are not to be viewed as sick or schizophrenic. The differences between the two types of hallucinations are the following: 1 , religious hallucinations are mainly visual, auditive elements in general being of lesser importance. 2, Contentwise, religious hallucinations often involve older people, parent substitutes, but they are kind parents who guide the person they reveal themselves to. 3 , The content is clearly benefical for the individual. 4, They lead to a marked increase in the individual's self-evaluation and a feeling of "his being or becoming a worthwhile and very active person". A more general difference is that "the hallucinatory and delusional experiences of the schizophrenic are generally accompanied by a more or less apparent disintegration of the whole person" (1974, 277).

Before we leave the primary processes, let us remember that these cognitive mechanisms can, according to Arieti, be activated in many ways. One possibility is that they occur spontaneously, like lightning. Among the ways we have previously mentioned are daydreaming, relaxation, intoxication, dreams, meditation and contemplation. This activation is followed by a further reworking on the secondary process level. "It is up to the mental faculties that are part of the secondary process to accept or reject this material" $(1976,84)$. What occurs there can generally be described as "the formation and use of concepts and their relations" $(1976,87)$. 
One example of how Arieti utilizes his model in relation to the mystic experience is the following. The contact with a divine reality that many religious figures mention is interpreted as an activation of primary processes, which function as supports for the secondary process. The religious revelation is often preceeded by doubt or conflicts. An important condition is whet Arieti in agreement with James (1904) and Laski (1961) calls "a state of overbelief', in other words, a foundation in a religious tradition. The mechanisms of the primary process can mean the solution to a conflict situation or can be seen as evidence that the deity is on the individual's side. One example of this is Constantine the Great, who according to Eusebius was preparing for battle against his rival Maxentius: On the 27th October $312 \mathrm{AD}$ he had a vision of a flaming cross in the sky coupled with these words: "In this sign thou shalt conquer". Constantine interpreted this vision as a divine exhortation to become a Christian.

Arieti views this vision as an example of concretizing or perceptualization of concepts. The Cross is a symbol of conversion to Christianity and a projection onto the outer world; the message to become a Christian, a step that Constantine as emperor of a heathen tradition dare not take himself, now came from God. The religious hallucination or possibly illusion, is the solution to the situation. The secondary process is now in harmony with the primary process. Constantine's conversion to Christianity, Arieti says, was influenced by the fact that his mother was a Christian. Additionally, it implied a tactical advantage. In Maxentius' army there were many Christians who perhaps refused to fight or at least fought less intensively against the Christian Constantine (1976, $249 \mathrm{ff})$.

With this instrument we have the opportunity to cast new light upon a decisive experience in the life of the Swedish mystic Hjalmar Ekström (1885-1962). However, a minimum of background information is necessary to understand this interpretation.

After ten years work in his father's shoeshop, the young Ekström was finally able to realize his dream of an active Christianity by studying to become a deacon. His high-flying expectations fell, however, after a couple of years work in the field. He left the deacon service in the spring of 1914, after a deep spiritual crisis. For one and one half years he wandered through Sweden to preach the simple teachings of Jesus, based upon the message of the Sermon on the Mount. Among the motifs predominating in his letters to his wife during this time, is the conviction of God's guidance in everything. "God guides in everything, may we be secure and happy and with courage follow his paths", he wrote in October 1914 (Geels 1980, 125). The necessities of life forced him to return to the deacon service in the fall of 1915 , a situation which must have created considerable conflict. The new 
position did not last long. In the spring of 1916 he requested leave of absence which lasted the rest of his life. He radically severed all ties with the deacon institute and the deacon service and thereby even with its Christian reference system. After all the difficult years he finally took a vacation in Örkelljunga and there had an experience which he several years later described as a mystical death. Despite his reticence concerning his own experiences, he gave the following account of this experience to a good friend as an answer to his pressing questions. "It (that is, the mystical death) is really, at least according to my experience, like a fire which cuts through everything and consumes everything, leaving nothing left for man" (p. 208). The experience's visionary and auditive elements are clearly expressed in a secondary text, written down by a younger friend immediately after Ekström's own account (see 157f, 247, note 18):

... he went wandering in the woods alone. The path led up a hill. Then it was as if the entire world fissured. It was as if God's eternal love and God's eternal wrath had met in one place like a bolt of lightning, "which flamed down and to the sides like a cross, filling all the heavens and the whole earth, consuming everything". At the same time, he heard a voice which said; "Hereafter the path becomes pathless". And he was cast out into nothingness, a resounding, empty nothingness. Heaven was empty and the earth was empty and Hell as well.-In the first moments he hardly knew whether he saw or heard even with his outer senses. He dimly recalled that it was as if the day of judgment had arrived. But he came to his senses again and continued on his way, tremblingly.

This story has much in common with Ekström's description of the Spirit's night of darkness in the published commentary on the Song of Songs. In that spirit's night, everything that is light, both outer and inner, turns to darkness and despair. But ...

... it perceives something in that dark night, it perceives an immense and crushing expanse of space above, out of which there echoes a single word: Nothingness, followed by lightning, as if from the centre and flaming downwards and to the sides like a cross, filling the whole of space, consuming everything.

The visionary element is similar in both renditions. However, the auditive element is lacking, the voice saying that hereafter the path becomes pathless, in the commentary on the Song of Songs. Despite the fact that Ekström does not mention his own experience in a single word of his commentary, we may be relatively sure that it represents a systematic presentation of an experience and development that is his own. The fact that the auditive element is lacking in the commentary can be interpreted as a support for Arieti's opinion that such elements for mystics are subordinate to the visionary contents.

In Arieti's terms, the experience can be understood as follows. The break 
with the deacon service, where Ekström had spent eight hard years, must have given rise to the question of whether or not he was still led by God. It was, after all, this motif that had come into the foreground during the preceding years. Was God continually with him when he had now so radically withdrawn from the vocation of deacon and expressed such a strong and occassionally aggressive criticism of Christianity in general? The conflict may have taken place at a subconscious level. It found its solution in the vision and audition of the summer of 1916. The vision of the lightning bolt in the form of a cross can be viewed as a perceptualization of Christianity's most central symbol, which is projected upon the outer world. The auditive element served as a reinforcement for the renewed insight that he was still led by God. Even if the path should become pathless, Ekström now knew that there was still a path. However, it became very difficult for him. His health vacillated increasingly, his loneliness was intense, and it took him approximately six years to verbalize the experience in a self-made religious frame of reference. He shared this mystic view of man and existence with a small group of people for whom he served as soul curer and guide on the path of mysticism. The dream of his youth to care for the souls of others was realized, after all, but in a difficult and extremely independent way.

Arieti is aware that some researchers would not consider such experiences as the one mentioned above to correspond to mysticism. According to Stace, the mystic experience is totally devoid of form or content. What Stace is referring to, writes Arieti, is a sort of endoceptual phenomenon which goes beyond time and space, an experience which does not necessarily need to be coupled with a divine dimension of reality $(1976,263)$.

\section{The Mystic's Techniques-The Activation of Other Cognitive Processes}

\subsection{Arthur J. Deikman-de-automatization and the cognitive mode}

Deikman's theoretical and experimental studies of meditation and the psychology of mysticism received much attention during the 1970's. Frits Staal evaluates his contributions as "the one promising kind of experimental work I am familiar with" (1975, 119). And Hjalmar Sundén writes that "his approach means an important step forward in the study of the psychology of religious mysticism" $(1970,46)$. Deikman has, during almost 20 years of studying meditation and mysticism, emphasized the techniques that mystics and meditators have utilized to achieve a cognitive change. He is, however, apparently hesitant when it comes to describing what changes have been 
achieved. In articles from the 1960's and 1970's he has also successively developed and modified his analysis, with the consequence that his conceptual apparatus has become somewhat inconsistent. What Deikman lacks, above all, is a total view of perceptual and cognitive development in the light of which perceptual changes in his subjects can be analysed. These faults can be compensated by Arieti's integrated model. I would like to point out however, that the proposed coupling of Arieti and Deikman is merely a tentative suggestion. I hope to be able to point out a course along which mystic research should work more than it has done in the past. We shall see that this theoretical foundation can even be fruitful for the interpretation and understanding of certain religious phenomena.

Deikman has presented two experimental studies on meditation (1963; 1966 a). In both cases the subjects were asked to concentrate on a blue vase for a period of 15 to 30 minutes without allowing either internal or external stimuli to distract them. The technique was called contemplative meditation or perceptual concentration. Already after the first short series of experiments, the subjects reported considerable changes in perception. The analysis of the taped interviews gave the following thought provoking results (1966 b, 331; 1976, 72).

(a) an increased vividness and richness of the percept- "more vivid", "luminous"; (b) animation in the vase, which seemed to move with a life of its own; (c) a marked decrease in self-object distinction, occurring in those subjects who continued longest in the experiments: "... I really began to feel, you know, almost as though the vase and I were perhaps merging, or that vase and I were ... It was as though everything was sort of merging ..."; (d) syncretic thought and a fusing and alteration of normal perceptual modes: "I began to feel this light going back and forth", "When the vase changed shape I felt this in my body ..."

How is one to explain these perceptual changes? In order to understand Deikman's reasoning here, we must first study his theoretical starting points. Some of the important concepts in this theoretical analysis are automatization and de-automatization. Automatization implies in short that man, through the socialization process and through learning, has access to a large number of stereotypical interpretation patterns, which are utilized in an automatized way to understand and interpret stimuli. When one looks out of a window and sees a park there is no need to think first about what one sees, but rather the interpretation occurs spontaneously. However, a blind person who had once again received his sight would not automatically find meaning and structure in the flow of stimuli. The nervous system must first be codified with these interpretation patterns.

Now Deikman contends, with the support of other researchers, that these stereotypical models can either partially or completely cease to function if 
one manipulates, so to speak, with attention. The result is an "un-undoing of the automatizations of apparatuses-both means and goal structures -directed toward the environment" (quoted by M. Gill and M. Brenman in Deikman 1966 b, 329). Gill and Brenman attempt to understand deautomatization as an "advance or retreat in the level of organization" (ibid.).

We have thus reached the next landmark in this discussion. If we are to judge whether deautomatization is a step forwards or backwards (regression) ${ }^{2}$ in man's perceptual and cognitive development, we must first answer a few questions pertaining to developmental psychology. Deikman refers here to Heinz Werner, whose orthogenetical principle underpins our ensuing discussion. This principle implies that "whenever development occurs it proceeds from a state of relative globality and lack of differentiation to a state of increasing differentiation, articulation and hierarchic integration" (Werner 1957, 126). This means that man's development leads to continual differentiation, while earlier developmental stages are integrated into a hierarchic structure. With the aid of such a principle we can speak of an "advance or retreat in the level of organization".

Now Deikman shows that the previously mentioned perceptual changes coincide on all points with Werner's characteristics of the child's and "primitive" man's thinking, a developmental stage which precedes analytical, abstract, intellectual thinking. Is it then a question of regression? Deikman seems unwilling to use this term. The reason is that deautomatization occurs in "an adult mind, and the experience gains its richness from adult memories and functions now subject to a different mode of consciousness" (1966 b, 331). Instead, he is most inclined to speak of changed states of consciousness, which are analogous to the experiences of the classical mystics. The results indicate, however, that meditation as a psychological technique "is a central element in the production of the trained mystic experience" $(1963,216)$. The majority of the subjects reported experiences that belong to the "sensate" category, that is, that they are based on common affects, sensations or conceptions (more on this below). But there were even indications of experiences of the transcendental type, beyond the "sensate" category. From a psychological perspective, however, the concept of transcendence seems to be problematical, a difficulty I shall return to later on.

In the article on deautomatization and the mystic experience (1966b), Deikman writes that the effect of deautomatization is amplified by the activities that mystics have always engaged in, namely various forms of

2 The concept of regression has lately become the object of criticism (see below $\mathrm{p}$. 46). 
privation, such as poverty, chastity, isolation, silence, and meditation. We are simply dealing with various techniques that the mystic utilizes to direct attention away from the world and instead become totally directed towards an experience of God's nearness. A further similarity between Deikman's subjects and mystics is that both learn not to react to distracting stimuli. Both groups develop psychological barriers, which EEG studies with Zen monks confirm (see for example Kasamatsu and Hirai 1963; Hirai 1978). There are, in other words, a great number of techniques which can elicit deautomatization. For the mystic these are, above all, privation and meditation. Deikman draws the following conclusions (1966, 337f):

A mystic experience is the production of an unusual state of consciousness. This state is brought about by a deautomatization of hierarchically ordered structures that ordinarily conserve attentional energy for maximum efficiency in achieving the basic goal of the individual: biological survival as an organism and psychological survival as a personality. Perceptual selection and cognitive patterns are in the service of these goals. Under special conditions of dysfunction, such as in acute psychosis or in LSD states, or under special goal conditions such as exist in religious mystics, the pragmatic systems of automatic selection are set aside or break down; in favor of alternate modes of consciousness whose stimulus processing may be less efficient from a biological point of view but whose very inefficiency may permit the experience of aspects of the real world formerly excluded or ignored. The extent to which such a shift takes place is a function of the motivation of the individual, his particular neurophysiological state, and the environmental conditions encouraging such a change.

In his last two articles $(1971,1976)$ Deikman places emphasis upon the previously discussed shifting between different states of consciousness. Meditation aids the shift from an active to a receptive cognitive mode. This model of a "bimodal consciousness" has been mentioned is earlier articles, but is now developed to a considerably higher degree. It integrates both psychological and biological variables, which are coordinated in two positions: "action mode" and "receptive mode".

The active mode is directed towards dealing with the environment. Seen physiologically this implies an activation of the musculature and an increase in muscle tone, while the EEG registers beta waves. Seen psychologically, one finds focal attention and dominance for the logic-objective thinking process. Perception of objects is steered to a greater degree by a priori concepts than by the experience of the senses. Perception of form dominates perception of color. The perceptual qualities of this "action mode" have developed so that man can influence the world with success.

Opposed to this active cognitive mode is the receptive mode, an organisational state which instead of dealing with the environment has the function of being receptive to it. The functions of the senses are more active than the 
muscular system. Now the para-sympathetic nervous system dominates. EEG readings tend toward the alpha and theta wave levels. Muscle tone is low. Attention is more diffuse and subject-object distinction becomes unclear, likewise the experience of ones own ego. Thought processes proceed along paralogical paths.

In order to illustrate these cognitive modes, Deikman gives two examples. A taxi driver who has been given the task of getting to the airport on time is totally preoccupied by this goal. He weaves through the traffic, sees things mainly as obstacles and is unconcerned with the colours of other cars. The blue sky or the beauty of the passing buildings he simply does not see. During this time his entire attention is concentrated on the streets and sideroads. He tries to remember alternative routes to the airport. His posture indicates tension and his EEG would without a doubt show quick beta waves.

In contrast with this taxi driver, the psychological and physiological processes of a monk are quite different. In the experiential world of the monk, the distinction between himself and the environment seems more dim. His muscles are relaxed and his EEG would probably register alpha or theta waves. In contrast to the taxi driver, he is not concerned with the future but is totally consumed by what he experiences at the moment.

The characteristics of both of these modes build a coherent system in the sense that a change in one of the system's components effects all the others. The choice of cognitive mode depends upon the individual's motivations. The completely dominating mode is the "action mode". This follows because, among other things, it is needed for survival, it is confirmed during childhood at the expense of the more basic receptive mode, and because, in a larger socio-cultural perspective, it is emphasized by western effectivity thinking. It is difficult for many to return to the receptive mode.

\subsection{The relation Arieti-Deikman}

A summary of Deikman's research results gives us the following picture. Experimental meditation leads to a shift from the active to the receptive cognitive mode, a shift that can result in a deautomatization of normal perceptual and cognitive functions. A possible result of this process can be a disturbance in the individual's perception of reality. "The sense of reality normally bestowed on objects is now 'transferred' to abstract psychical entities" (Deikman 1966a, 111). Deikman calls this phenomenon "reality transfer". To my way of thinking, this is most reminiscent of what Arieti calls the perceptualization of concepts. Another possibility, according to Deikman, is that the perception is broken down in the direction of a more primitive visual experience. Arieti calls this dedifferentiation (above p. 32), 
a concept which Deikman seems to use in approximately the same way $(1963,335 ; 1966$ a , 110 f). Dedifferentiation, writes Deikman, can also lead to an experience of unity, when "the self is no longer experienced as a separate object and customary perceptual and cognitive distinctions are no longer applicable" (1966 b, 330). Through perceptual concentration, the individual can become aware of certain intrapsychic processes which are normally withheld from consciousness. Deikman refers here to Heinz Werner, according to whom development implies, among other things, a structuring of the perceptual and cognitive world, a selective process, which occurs at the expense of certain stimuli. It is possible that the individual in these experimental conditions experiences intrapsychic, amorphic processes. Another logical possibility, Deikman continues, is that the individual perceives a characteristic of the phenomenological world (1966 b, $334 \mathrm{f}$ ). These experiences are strongly reminiscent of Arieti's description of endoceptual experiences. By these comparative examples I hope to show that Deikman's results can very well be viewed in the light of Arieti's psychology. A few circumstances facilitating a coupling of these two researchers is that both begin from a "general systems approach" and that both build to a large extent on the developmental psychology of Heinz Werner.

Deikman's concept of deautomatization and Arieti's cognitive model can be seen to complement one another. Deikman has studied the techniques which lead up to a psychological process, but he is unsure of how to describe this process. Arieti continues where Deikman stopped: deautomatization can lead to a situation where more primitive cognitive mechanisms, repressed by the environment's demands for secondary processes, can be reactivated.

Such an activation naturally need not only occur through renunciation and meditation. There are a considerable number of other techniques which mystics utilize within different traditions. Many of these classical exercizes entail that the individual is either placed in a situation of sensory deprivation, a state where a minimum of stimuli can be received, or a situation of sensory overload, where, for example, sight or hearing senses receive a given stimuli over a long period of time. The research on this phenomenon from the 1950's can, according to Arieti, be summarized in the following way. When a person is first put into a situation of sensory isolation, she experiences in the beginning a hunger for stimulation, then "indulgence in reveries occurs, finally the reveries assume a perceptual quality and become hallucinations, predominantly or exclusively of the visual type". Similar phenomena have been reported earlier by people who have through certain circumstances been placed in a situation of understimulation, for 
example, lone seaman or polar explorers. According to a theory of L. J. West,

effective sensory input ordinarily serves to inhibit the emergence into consciousness of previously recorded precepts. If effective sensory input is impaired, recorded perceptual traces are released and emerge. According to West, effective sensory input can be impaired in three ways: (1) absolute decrease or depatterning; (2) input overload, or 'jamming the circuits'; (3) decreased psychological contact with the environment through the exercise of mental mechanisms (dissociation).

West believes that if, at the same time as the input is decreased, there is sufficient internal arousal of the brain (through the reticular formation of the brain stem) to permit vivid awareness, the released perceptions may be dynamically organized and reexperienced as fantasies, dreams, or hallucinations (quoted in Arieti 1974, 272f).

This theory is of importance for the understanding of diverse phenomena within the psychology of religion. One example is the repetitive prayer, which exists in different places throughout the religious world, above all, in Islamic mysticism or Sufism. Through a persistent repetition of God's name, combined with specific body movements and a special breathing technique, the Sufis place themselves in a situation of "input overload". It is interesting to note that sensory under- and overstimulation, at least at one level, appear to be two sides of the same coin, as overstimulation occurs at the expense of other stimuli. These phenomena are also related to ecstatic dance, to overstimulation of the sense of hearing through rhythmic music, and to cries of hallelujah at charismatic meetings, to give only a few examples. There is here a great area for research in the psychology of religion.

If we return to the comparison between Arieti and Deikman, we can state that traces of Deikman's so vital distinction between active and receptive cognitive modes are also found in Arieti. In connection with the neoFreudian Ernest Schachtel's division into autocentric and allocentric perception, that is, perception with a low degree of objectification and a predominance of feelings of lust and discomfort, and a perception which actively directs itself towards the object (Schachtel 1959, chp III), Arieti remarks that this deals with important attitudes, but is not sufficient for creativity $(1976,28)$.

Schachtel's distinction has a number of intersecting points with the active and receptive modes (van der Lans 1980, 79 ff). If I interpret Arieti correct$\mathrm{ly}$, the receptive mode and allocentric perception can be creativity promotive cognitive attitudes. On images on the level of the primary process, for example, Arieti writes: "Images occur spontaneously, but they are made to occur more easily if the person refrains from action and if external stimuli are reduced or eliminated. Rest, solitude, and meditation facilitate their 
occurrence" (1976, 46. My italics). Among the nine "simple attitudes" and the circumstances which promote creativity in the individual, he lists first aloneness, thereafter inactivity, and daydreaming as the third point. In other words, three conditions which are not valued in western successoriented society. Through aloneness the individual is less susceptible to the influence of society and its clichés, a sort of partial sensory deprivation, which facilitates the manifestation of the primary process. When it comes to the choice of cognitive mode, the authors seem to be in agreement.

It appears that Deikman has also seen something of Arieti's tertiary process. The shift to the receptive mode can, according to him, give rise to creative intuition. The first phase in this process is characterized by an intensive struggle with the problem (action mode). When one is conscious of having arrived at a dead end, a stage of self-surrender (receptive mode) ensues, during which the answer can come like a flash-the creative synthesis. During the last phase, one shifts back to the active mode in order to integrate the new formulation with previous knowledge and in order to share it with others (Arieti 1976, $83 \mathrm{f} ; 1971,83$. Compare also Wallas's (1926) four studies of the creative process). It is however clear, as we have already suggested, that the value of Deikman's deautomatization concept and the cognitive modes lie on a different level to that of Arieti. The relationship between Deikman's and Arieti's concepts then is that they complement and partially overlap one another.

\subsection{The concept of regression}

One central question which we previously mentioned (p. 41) is whether an activation of more primitive cognitive processes implies a regression to an earlier stage of development. One of the leading figures in this field for a number of years was the neo-Freudian, Ernst Kris. In his work on the psychology of creativity $(1950,1952)$ Kris suggested that creativity should be understood as "regression in the service of the ego". The creative individual has access, so to speak, to primitive cognitive processes without losing contact with reality. The difference between creative and schizophrenic regression is that the former implies a temporary regression while the latter implies a more permanent one.

In latter years, the concept of regression has been the point of critical debate (Kragh and Smith 1970; Rothenberg 1979, 1981; Suler 1980). Kragh and Smith point out that the concept of regression could easily become misleading because of its clinical connotation. The authors feel that instead of talking of regression one should talk of reconstruction, a concept which implies that subconscious or preconscious material "is exploited within the 
frame of an individual's present perceptual-cognitive activity" (Smith 1981, 4). In connection with Rothenberg (1981) Smith comments that the activated cognitive processes do not apparently represent "a primitivization of mental functioning although they utilize certain aspects of primary process characteristics beneficial to creativity' $(1981,6)$. I believe that this is an important point, which harmonizes with the integrated hierarchical model previously presented, based upon Heinz Werner's developmental psychology. With a starting point in Rothenberg and Smith, I shall therefore speak of reconstruction (more on this concept follows on $\mathrm{p}$. ). A reflection comes to mind, however, concerning intensive religious experiences. It would seem reasonable to assume that secondary processes are more or less connected to primary processes. The predominance of the former or the latter might be a function of the intensity of the experience. During intensive experiences the secondary thought process is inhibited completely, during less intensive experiences only partially.

\section{Two Problems Often Discussed within Mystic Research}

\subsection{Types of mystic experiences}

Many pioneers within mystic research have worked with typologies in order to differentiate between mystic experiences. One of the first was presented by William James. His division into cultivated and sporadic mysticism (1904, 393 ff) still seems to be of use. Deikman utilizes a similar division which I shall come to shortly. One advantage of these typologies is that they are free from apologetic elements, which cannot be said of many other classifications in mystic research in the 20th century. One exception is James B. Pratt, who in his classic study on the psychology of religion from the 1920's differentiates between mild and extreme experiential types. The former is found in completely normal people, while the latter is usually "so striking in its intensity and in its effects that it attracts notice and is regularly regarded as a sign either of supernatural visitation or of a pathological condition ... And in these more intense cases of mysticism the simple 'sense of a Beyond' develops into the ecstasy and the vision" (1926, 339).

What is interesting in Pratt's distinction is that, like James, he was aware that there are differences in mystic experiences with regard to intensity, which implies that such experiences in their less intensive forms are more common than is generally assumed. There is a tendency in older mystic research to consider the mystic experience as unique, unattainable for the 
average person, remote from his day to day life. ${ }^{3}$ Marghanita Laski has a completely different view. In the very title of her book Ecstasy, a Study of some Secular and Religious Experiences, she expresses the view that this type of experience is not unique to the world of religion. She has the support of the well-known humanistic psychologist Abraham Maslow, who has lowered, so to speak, the religious prophet's and ecstatic's "corereligious" or transcendental experiences to the level of everyday psychology. "It is very likely, indeed almost certain, that these older reports, phrased in terms of supernatural revelation, were, in fact, perfectly natural, human peak-experiences of the kind that can easily be examined today" $(1973,20)$. One consequence of Maslow's view is that in a western secularized society of the 1980's we utilize a different language than that used in an older society, where religion played a more important part as a pattern for interpretation of diverse experiences. We are once again dealing with sociocultural factors, which always play a central role. It is quite apparent that in the pluralistic society of today, with its strong influence from meditation movements of the East, for example, it is much easier to talk of religious and mystic experiences. Indeed, mystic experiences appear so common today that the American sociologist of religion, Andrew Greeley, asks in an article from 1975, "Is America a Nation of Mystics?" His survey study showed that four out of ten Americans had had, or believed that they had had, mystical experiences. The American Gallup study of religion showed similar results in their index from 1977-78 (quoted in Ellwood 1980, 1f; Hay 1978; Hay and Morris 1979).

Arthur Deikman has in his studies of mysticism presented a distinction which, with certain additions and restatements, can be of practical value. $\mathrm{He}$ differentiates between "untrained-sensate, trained-sensate, trained transcendent" types $(1966 \mathrm{~b}, 324 \mathrm{f})$. In the first category, which is largely commensurate to the previously mentioned sporadic type, are included people who normally do not engage in prayer, meditation or other exercises. This category also includes the majority of intensive experiences elicited by drugs. James gives many examples of experiences elicited by laughing-gas, chloroform and ether. After the second World War, especially during the 1960's, many studies were done on the importance of psychedelic drugs for mystic experience (Geels 1980 a). These experiences, however, need not always belong to the spontaneous category. The question of with what intent and in what kind of environment drug usage occurred, in

\footnotetext{
${ }^{3}$ A similar tendency has been found within the field of creativity research, where the great geniuses are often emphasized. The modern view seems to be, however, that the
}

creative process is similar both with regard to various subject areas and to various degrees of intensity. 
other words, the set ard seting, is of decisive importarce. There is a great diference, especially in set and seting, between, for example, the North American Indians' peyote rites and the hippie culture's uncontrolled selfexperimemtation with 1 SD-25, mescaline or psylocibin during the 60 's.

It can be difficult to differentiate between the categories "untraned. sensate" and "traned-sensate" if one only studies the texts. The difference is that the latter consciously and with the aid of given excrcises strive towards a directly experienced relationship with God. The socio-cultural difference is of decisive impontance. The trained mystic often functions in a special enviromment, for example, the monastery life, and has a system of concepts at his disposal with which he can interpret his experiences.

The great mystics as well as their commentators, writes Deikman, "di. vide the effects and stages through which mystics progress into a lesser experience of strong emotion and ideation (sensate) and a higher, ultimate experience that goes beyond affect or ideation" (1966b, 325). "The latten experiential type belongs to the "trained-transcendent" group, a state where multiplicity steps back for a sort of experience of wnity. Such experiences are often the result of considerable practice. An important difference, Deikman states, is if the experience is founded upon nomal affects, sensations and concepts, or if it is reported to extend beyond them $(1966 \mathrm{~b}, 327)$

I believe that one experiential type is missing anong Deiknan's distinctions, namely the "untrained-transcendent" category. Transcendental experiences in Deikman's sense can also occur sporadically or spontancously. Often it is this type of experience that Zaehner (1967) calls panenhenical, unity in existence. Instead of the categories "sensate" and "transcerdent", I slggest, therefore, a differentiation belween structured and unstructured experiences. By structured is meant a clearly discemible content, for example, the free of Christ, a figure and so on. The experience is unstuctured when the individual refers to more abstract categories such as cmptiness, nothingness, peace, light and so on. These two types are to be viewed in relationship to the two qualitites of cultivated and spontaneous. We then gain the following axial system.

$$
\text { structured - } \frac{\text { trained }}{\text { spontaneous - unstictured }}
$$

There is one disadvantage with the concept par sensate-lrascondent. Since the human organism always strves to provide stimul with meaning. and since the mystic experience always contains some fom of stimuli, the concepts are poorly chosen. The question becomes rather, what son of strmul are we dealing with? From this point of viow, the concept pan

4-Religious Eostasy 
structured-unstructured is more appropriate. At this point, I should also like to add that I am sceptical of the concept transcendence in Deikman's sense. An experience must always have some sort of content, otherwise it is not possible to communicate it. On the other hand, the content can be of a completely different type to that which is experienced in everyday life. What is lacking is a language with which to communicate it. Another side of the transcendent is that the individual's experiential platform is not the ego that he is used to identifying by, but rather a "deeper" dimension of personality. That which one "goes beyond" (transcends) is one's own identity. After the experience, the ego concept is extended. It is in this sense I feel that one should understand humanistic psychology's talk of self-realization and expansion of consciousness.

\subsection{Mystic experience and interpretation-a perceptgenetic view}

It is mainly the philosophers of religion who have shown an interest in the relationship between mystic experience and interpretation. Since the beginning of the 1960's there has been a clear distinction between a mystic experience and, in the words of W. T. Stace, "the conceptual interpretations which may be put upon it" (Stace 1960, 31 f). According to Stace, this distinction is comparable to the relationship between a perception and its interpretation. The former relationship is, however, very difficult to get at. By interpretation Stace means "anything which the conceptual intellect adds to the experience for the purpose of understanding it" $(1960,37)$. Stace's concept of interpretation belongs, in other words, to the reconstruction phase and to a phase which can occur after the first description of an experience. I will return to his perspective on the experience- interpretation problem. In any case, we are dealing with the conscious reworking of an experience on the basis of a given tradition.

Stace inspired researchers in various places to examine this problem (see, for example, Smart 1962, 1966; Hof 1967). One of the latest and most indepth examples of analysis of this problem from the perspective of the philosophy of religion was made by the Englishman, Peter G. Moore. In an article from 1973, Moore points out that mystic research has underestimated this problem. His contribution consisted of a recommendation for three "possible junctures at which interpretation could relate to experience" (Moore 1973). Five years later the distinctions were increased to four, which indicated that Moore himself had also underestimated the problem. The first type is called "retrospective interpretation", that is, interpretations influenced by tradition arising after the experience. Moore did not however, discuss what importance the time interval had for ex post facto 
descriptions. From a psychological perspective, however, this is a not uninteresting detail. The majority of descriptions of mystic experiences are given long after, perhaps years after, the experience itself. The intention of the description is also important to note. When dealing with old texts, even various Church censorship bodies can have played a part. In any case, one must take the knowledge of memory psychology into consideration with regard to retrospective interpretations.

The second type Moore calls "reflexive interpretation", spontaneous interpretations formulated during the experience or immediately thereafter. When the mystic's own beliefs, his expectations and intentions influence the experience, Moore speaks of "incorporated interpretation". This third type is divided into two subgroups: "reflected interpretation", ideas and images that are reflected, so to speak, in the experience in the form of visions and such; "assimilated interpretation", the experiential type which builds a phenomenological analogy to a belief or doctrine. And the last type in Moore's categorization consists of experiences which are supposed to be uninfluenced by the mystic's earlier belief, expectations or intentions. He speaks in such cases of "raw experience" (1978, 198f).

Let me add immediately that the latter category is a theoretical abstract. From the psychological point of view, the mystic's original experience is very difficult if not impossible to get at. Further, it is unthinkable that the individual is totally uninfluenced by earlier life developments. Researchers always work with interpreted experience, most often verbalized in various forms. However, it is possible to speak of "raw interpretation". But this category coincides, as far as I can see, with that of "reflexive interpretation".

The most important contribution of the above mentioned philosophers of religion is that they have been aware of the various levels of interpretation concerning mystic experience. One must agree with Peter G. Moore, however, that it is the psychologist's task to clarify the relationship between experience and interpretation (1973, 178). Moore emphasizes the importance of the individual's cognitive structure before the experience. No more comments of a psychological nature are to be found. It is therefore apparent that a psychological conceptual apparatus is needed to carry this discussion a step further. With the aid of percept-genetic theory, I feel that a new perspective is unfolded.

Before we consider this new perspective I would like to direct attention to an almost trivial point, which is a consequence of both the previously presented cognitive model and of analyses by philosophers of religion. The text which the psychologist of religion studies must be seen as a conscious and developed final product of a process which has a number of sub- and 


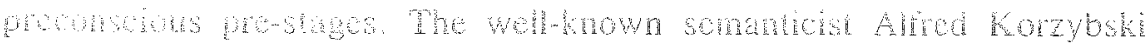

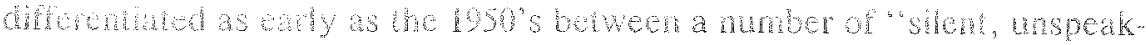
able leves" when roced the verbul fixation of an experience (1951, 172).

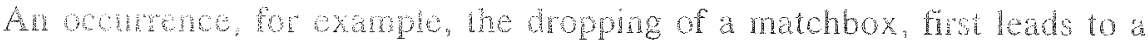

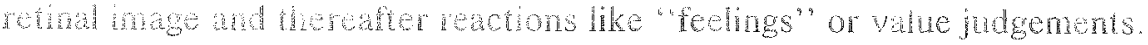
These phes in the percenal nocess are still to be found on a preverbal level. The lrot hase in this greaty smplited model is the varous forms of mantation wh the ard of the langage system (1951, 172 fo). When ceding wh these sysems, Gozybsk diferentotes between primive and

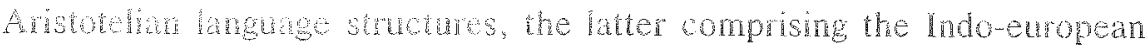
Lavgukes. The tomer are chatedized by a lack of abstraction and

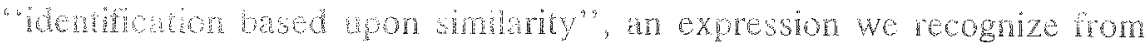

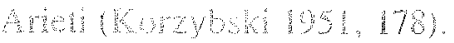

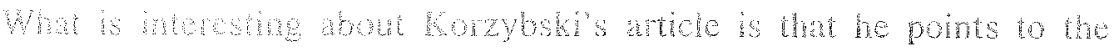

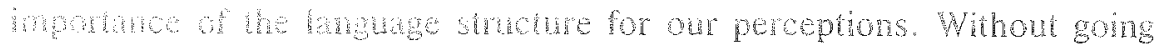

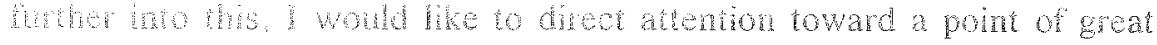
mpwhne tor the potom of how an urspeababe experience is interpret-

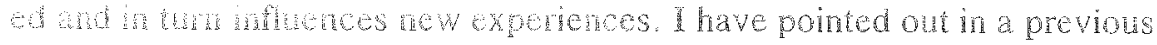
wor thet anstic must at some point have had his first mystic experionce and thereby a posble problen ol how to describe whe words the "indew schbobl" (Geds 1900,271$)$. It is this that the former American psycholoGel Rowat Alpet, now han Dass, calls a "labeliteg conflict" (1977, xif). What wat trme of reforence is one to interpret an intensive experience? Ram Dxss chose a whous interitution, accepted the consequences of ths and let ho job as arentemio teacher. Such a conflict, however, need

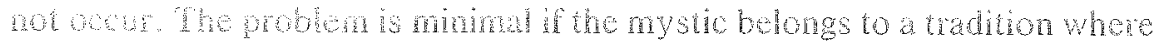
experiches of this type are a possibity and indect something worth string tor. In that case, there ane probably what social psychologists call

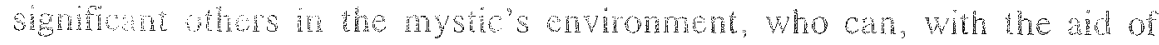

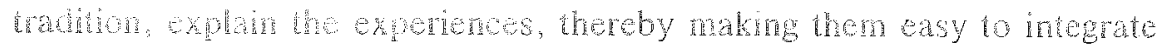

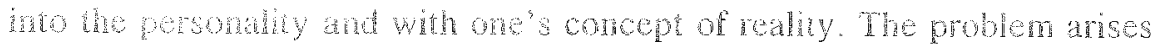
when the mysto does not have access to a mystic tradium. In such cases a the lapse will motably be found between the orginat expertence and irs verbazhon. The is wot an whut phenonenon in the context of mensive rolgows experiences One of Shri Aurobindos biographers mentions

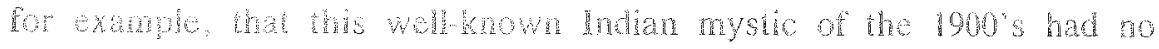

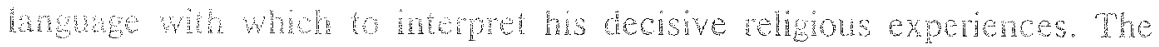
explantions cano much later (sec Goteman 1975, 207). It is then possible

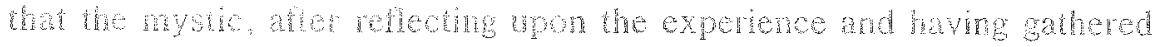
mor homaton hom thermstics, subsequenty ads new tomulatons

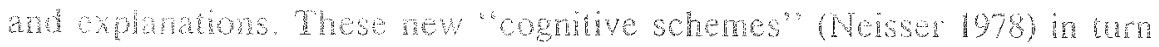




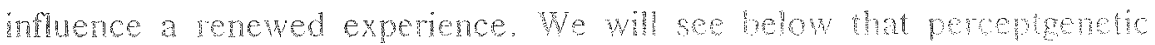
theoreticians suport such a view.

This aspect of the experience interpretation problem is also conthmed by Korbyski"s research, according 10 which "all languages have a struchure of some kind, and every langhage reflects in its own structure the worth as assumed by those who evolved the languge. Recipocally. we reat mosty unconsciously into the world the structure of the haguge we use" (1951, 177). A charication of this mutual relatonship between language and experience is that we expect the lanse of time betwen the exprience and its intemetation to become shoter when the mystic posseses a cognitive

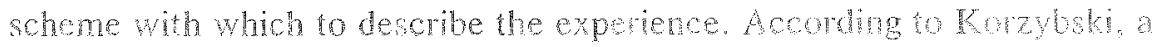
lingustic fixation always implies a risk; we tend to identify the verbatizawon with the preceding preverbal levels. However, "statements are verbn. they are never the silent "it" (ibid, 173).

If one assumes that the mystic experience is some sont of percepton, which is a common assumption, then the perceptgenetic argunent should be of the greasest importance for the experience-interpetation problem. Viewed in this way, ar intensive religions experience should follow the same psychological process as all other perceptions. The big difference is clealy the degree of intensity. It is important to keep this in mind when comparing mystic expentences and the perceptual process

The perceptgenetic resertoh at the Unversiy of Lund is linked to preWond War II continental psychology, monding the developmenal psychology of Weinz Wener, so important for our model, In commection with

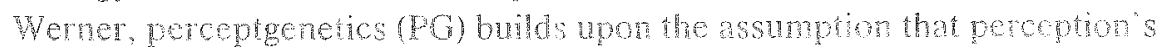
microgenesis, that is, is development durng a very shom perion of the, is related to the individual's ontogenesis, that is, her personal and personalty development (Westerlundh 1976, 313; Smith and Westerund $1900,95 \mathrm{~T}$ ), With the aid of various techniques, one atrompto to pt the dimerent subconscious-or more correcty meconscious-pestages of conscive

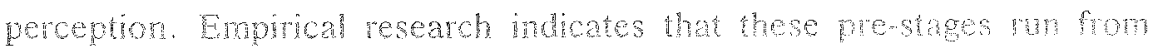

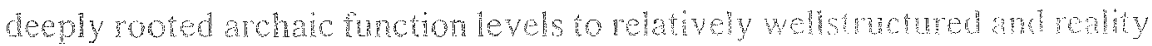
adapted levels. The development from the subective prominary phases (so-called Phases) wo the conchuing C phase ("condudng") is descrbed as a construction in the direction of the object. It is durng the phes that the indival, in the contey of her own life development gres moning to

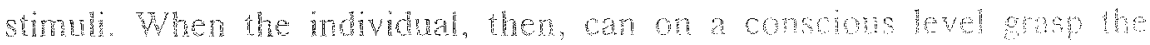

\footnotetext{
4 The develomment of percept-genetics arises on of expriments in poreption. For a revew ses ragh a Smith 1970 : Smin s. Westerinth 1980. The concept apparatus of
}

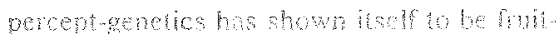

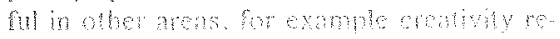
serich. 
constructed contents, she is influenced partially by her current cognitive structure and partially by her defense mechanisms. The latter is called reconstruction, a concept we have met earlier (p. 46). On the relationship between construction and reconstruction, Smith and Westerlundh write $(1980,113)$ :

... during our lives, we will consciously experience more and more (reconstruction). This successive experiencing is incorporated in the life-historical meaning system and is thus activated in later acts of construction. In terms of the historical personality, the act of construction implies an activation of the individual's earlier reconstruction.

Perceptgenetics assumes that perception, during this construction from phase $\mathrm{P}$ to $\mathrm{C}$, can go through many "descriptive transformations". The first is cumulation, the retention of previously gained insights; the second is elimination, an exclusion of material via an automatizing process; the last is emergence, the development of new insights (Westerlundh 1976, 313; Smith and Westerlundh 1980,111 ). Transferred to the area of mysticism, cumulation is commensurate with what Moore calls "incorporated interpretation". Cumulation implies namely, that there is a certain continuity between the individual's "life history", where faith and expectations are a part, and experience. Such a continuity is probable when the mystic's intensive perception is structured, for example, in the form of the face of Christ or perhaps a voice that speaks to the individual. Visions and auditions, in other words, should reinforce rather than demolish a religious frame of reference.

If we return again to Moore's categories, we can, from a psychological perspective, combine the reflexive interpretation and the "raw experience". As far as his third category, "incorporated interpretation" is concerned, it can possibly explain the cumulation effect, but not the emergence phenomenon. The first category, the retrospective interpretation, is too broad to be of use, for Moore does not seem to have considered the time lapse between the original experience and later additions, repressions, and other changes. (Regarding regulatory aspects and the psychology of memory see earlier work (Geels 1980)).

Over and above the previously mentioned points concerning the latter problem, I would like to direct attention to a similar phenomenon within psychoanalysis-the interpretation of dreams. In his classical work on dreams (1900) Freud assumes that dream contents are successively reinterpreted. Through this reworking, dreams gain a better logical construction and inner context. Since the later versions are steered by the secondary process, Freud calls this reworking secondary revisions. 
I believe that this concept is of interest for the experience-interpretation problem. Gronbaek (1935) has from the direction of the psychology of religion, shown what principles are active in post-descriptions. The four tendencies that he found, including the order and intellectualization tendencies, are all of the secondary process type. What is not clear in Gronbaek's results, however, is the tendency to add to previously made interpretations or the tendency to practice censorship, so to speak, of one's own interpretations. This can be motivated in both cases by the mystic's need to integrate the experience into the religious frame of reference (inner motive) or by the environment's demands for orthodoxy (external motive).

One example of a secondary revision is the following quotation by Martin Buber (1961, 43):

... from my own unforgettable experience I know well that there is a state in which the bounds of the personal nature of life seem to have fallen away from us and we experience an undivided unity. But I do not know-what the soul willingly imagines and indeed is bound to imagine (mine too once did it) - that in this I had attained to a union with the primal being or the Godhead. That is an exaggeration no longer permitted to the responsible understanding. Responsibly - that is, as a man holding his ground before reality-I can elicit from those experiences only that in them I reached an undifferentiable unity of myself without form or content. $/ .--/$ This unity is nothing but the unity of this soul of mine, whose 'ground' I have reached ... (italics mine)

Buber refers here to an experience of undifferentiated unity, which he at one time interpreted as a unity with God. However, based upon what he terms "responsible understanding", that is, loyality to his own Jewish tradition with its strong emphasis upon a transcendental God, he calls this previous interpretation an exaggeration. Instead, he chooses to interpret this experience as an experience of unity with his own soul, without God being involved. In other words, it is a clear example of secondary revision.

\section{The Mystic Experience and Creativity}

The concept of emergence is very interesting for the psychology of religion. In creative people, emergence is combined as a "revolutionary" principle with the conservative influence of accumulation (Smith 1981). I believe that it is reasonable to assume that the possibility for new insights increases when the mystic's intensive perception is unstructured, for example, an experience of unity in nature, an intense experience of light, peace etc. Seen psychologically, such stimuli should be a good starting point for the primary process in Arieti's sense. Experiences of an endoceptual nature or 
paleological thinking or a transition from the forner to the latter should be factors that greatly facilitate a rich picture language, metaphors, paradoyes and possibly new linguistic constellations. Its not surprising, then, that the two great linguistic reference systens, the profane and the religious, merge into one another.

With the concept of emergence we have also provided a link between perceptgenetics and our model of perceptual and cognitive development. For perceptgenetics does not describe how emergence's new insights come to the individual, onty that they arise. According to the model based upon Arieti and Wermer, we are dealing with the activation of processes that can lead to creativity. In addition to the (un)structured nature of the experiences, even defense mechanisms and socio-cultural factors play an important role. In dealing with historical mystics however, it is difficult to get at the former variable, which makes a psychological study even more cifficult.

It is apparent that the unstructured intensive experience is of the greatest importance for the activation of cognitive processes that aid creativity. Emergence leads to new insights, new contents. It is a well-known fact that many of the classics of world literature are the contributions of religious mystics. Inar de la Cruz's Cantico is judged to be "avec deux ou trois sonnets de Gongora, ce que la poésie espagnole a jamais produit de plus étrange et de plus sublime" (quoted in Sundén 1970, 35). Among the mystics less bound by tradtion we find both Plotinos and William Blake. Examples are many. One can say in any case that intensive religious experiences have motivated mystics to write and often led to hterary masterpieces.

Intensive religious experiences can be seen, in other words, as a motivational factor. We must remember, however, that the verbal expression of this represents only one of a number of reaction patterns (see p. 36). The methodological problem for researchers is to find criteria for the creative process, a very important problem which I shall come to shortly. The combination of primary and secondary processes discussed above is to a large extent a hypothetical construct. It should perhaps be said here that Arieti is not the only one to present a dichotomy of the creative process. Other researchers who have had similar ideas include $D$. Rapaport, $A$. Maslow and U. Neisser (see Ruth 1980, 25). Even A. Koestler's (1964) distinction between associative and dissociative thinking indicates similarithes with this dichotomy.

Mariane Jeffmar is one of those who has taken research a step further. Instear of using a dichotomous model, she works with a trichotomous model which serves her purpose of explaining the similaritics between intelligence and creativity. She differentiates between three cognitive pro. 
cesses: a primary imaginative process and two secondary processes, the ductive (inductive, deductive) and the ammotating process. The imagnary (1) process is described as intuive, global and sensitive. The ductive (D) process is analyzing and abstractive, nut the annotative (A) process is observant and ordered. The I process is the least dependent and the A process is the most dependent upon the enviromment (Jeffmar 1978; $1978 \mathrm{a}$, 161). The combination of the 1 and D processes can lead to creativity. whille the combination of $D$ and $A$ processes gives rise to intelligence. It is worth mentioning, however, that the I process in comparison with Arieti's primary processes, is a more limited category. It is manly of a cognitive type, while Arieti's primary processes are of both a cogmive and affective natire.

In a later work, Jefrmar (1980) suggests in connection with Ornstein et al, that the I and D-A processes have their physiological counterparts in the specialization of the wo brain hemispheres, a coupling which acquired new topicalty when Roger $W$. Sperry was awarded the Nobel prize in medicine in 1981 for precisely similar research. The loft hemisphere's logical-analytical thinking is commensurate with the secondary processes, while the right hemisphere's spatial and holistic specialization is commensurate whthe pre-and subconscious primary processes.

Jefrmar has also contributed with suggestions conceming the previously mentioned problem of funding criteria for when the the creative process has been active, in other words, to operationalize these processes. A subpro cess to the 1 process is syncretim, "a tendency to build un new combinations and/or conglomerations of disparate concepts or elements in an emotional way. Syncretism can also be described as a tendency to keep separate phenomenon and fact, feeling and perception. The term syncretism is borrowed from Werner (1948) who used it to describe 'primitive" cognive functioning." A subprocess to the D process is flexibitity, that is, "a tendency to interpret phenomena andior facts intellectually in different and/or new ways." Exactness, finally, is an expression of the annotative process $(1978 \mathrm{a}, 17 \mathrm{f})$. I believe that these subprocesses are arpincable to mystic research. A good reason for supplementing with Jefrmat is that, like Arieti and Deikman, she starts from a "systems approach" and, as we have seen, also builds upon pars of Heinz Wener's theories.

It is not difficalt to find examples of syncretism in the mystic texts. Ont of consideration to space, I will himit mysell to a few. On a general hevel, the mystic's rich flora of pictures, metaphors and symbolic language can be viewed as an expression of vertal symctism. The use of pictures and metaphors cleary coincides with the most imponant characteristic of the mystic experience -its indescribability. The pressing need to somenow 
describe the indescribable can lead to metaphors, among other things. According to Arieti, they offer the opportunity to express "the similar in the dissimilar". 5 Even Aristotle understood the importance of the metaphor: "The greatest thing by far is to be a master of metaphor; it is the one thing that cannot be learnt from others; and it is also a sign of genius, since a good metaphor implies an intuitive perception of the similarity in the dissimilar" (Poetics, 1459 A. Quoted in Arieti 1976, 136).

Another example of syncretism is the tendency for many mystics to assume relatively freely the ideas and wordings of other authors. The combination of what in themselves are old words and phrases leaves us with something new, a unique combination of ideas. We can call this ideational syncretism. We should not however forget the socio-cultural environment, for example, the possibility to express oneself freely, without external demands for orthodoxy. Thus Hjalmar Ekström in twentieth century Sweden can use a very old image which it would not have been possible to interpret in that way in the Catholic Europe of the 1300's. The image contains two components, iron and fire, which illustrates man's relationship to God during unio mystica, the mystical unity. As iron's characteristic qualities disappear when it is glowing red, so also does man's nature disappear when consummed in the divine fire. But, Ekström writes in November 1929, "the more often the iron is in the fire, the more it is consummed by the fire, until nothing is left, and the iron has gone to another existence" (Geels 1980, 209). Ekström refers here to the dissolution of the personal identity in the mystic experience, a unity with God in the sense of a coalescence, a wording which would not have been allowed in another time and place.

New linguistic constellations, such as Simone Weil exemplifies, can be seen as an example of flexibility. The phenomenon is well-known and is similar to the linguistic mobility that many mystics bear witness to. Here we have reached the subprocess of flexibility. It can go together with the unstructured nature of the experience and the mystic's independent attitude in relation to tradition. An example of this is once again Hjalmar Ekström, who in certain collections of letters utilizes a language with a strong infinitudinal coloring and in others describes the mystic experience with concepts taken from the personality category. One example of each will illustrate this phenomenon (see Geels 1980, 193-213). On his experience of God Ekström writes:

\footnotetext{
${ }^{5}$ Compare Hans Hof's analysis of analogia attributionis with Meister Eckhart (Hof 1952).
} 
it's as if you are sucked up and drown in Him in heaven and become one with Him, as if nothing else exists except Him, no other will except His. This unity cannot be described with words, it is full of the wonders of heaven and earth ...

$1--1$

Yes, everything drowns in God's transparent stillness and in It becomes as one: everything is transparently transformed, everything becomes as crystal, until one for a moment or a while falls back into one self ... And so the Heart's space opens again, more widely than before, radiating with great light, and so bubbling with life that the body staggers and shakes (consumed as the flame consumes the wax-'life blooms with a swaying crown') (Italics Mine).

This description with its clear feeling of infinity can be compared to the next quotation which is characterized by fertility, pregnancy, and birth symbolism:

And with this seed of life he fertilized everything that believes in Him, so that His heavenly body and spirit was born in it (to be born out of it in its time). During the time that the new life grows within man, man is taken ever closer to the death of the old, for the new and the old life can never be united-the one must do away with the other.

The concepts born-in and born-out are probably new linguistic constellations, possibly influenced by Master Eckhart. Other examples of creative reactions of the flexibility type are where old terms or doctrines receive new meaning. In this category we may also include the innumerable commentaries and personal explanations of religious texts that one often meets. In certain religions, for example, Hinduism, it has become a tradition that the great leaders of the various religious branches should comment on the texts that are common for all the religious branches. For Christianity I will give a couple of examples. Jan van Ruusbroec builds his most important work "The Spiritual Marriage" on the Bible verse "Behold, the bridegroom cometh; go ye out to meet him" (Matt. 25:6), a Bible verse that he then comments on for 150 pages! It is clear that with this commentary he strayed far from the exegesis of his time. Another example is commentary, common with in Christian mysticism, on the Song of Songs. Hjalmar Ekström's personal commentary, published in 1937, is one of the latest examples of such creativity.

\section{Conclusion}

The aim of this article was to provide a partially new method for mystic research, largely by utilizing modern research from the psychology of creativity. Much has happened during the last decade in the area of creativity. This research, in turn, has been strongly influenced by the new direc- 
tion within the development of psychoanalytic theory during the 1960 s and 70 's. Central concepts such as the primary and secondary process and regression have become the objects of revision and enpirical testing see for ex. Suler 1980). These aspects are of great importance, I feet, for creativity as well as for mystic experience. Much, however, remains to be done. It is my intention to test, with the aid of the hypotheticat-dednctive method (Maess 1980), a number of the consequencas of the previonsty presented theoretical view. It is therefore important to work with individuals that are still alive. Since many studies fror ex. Greley 1975 . Hay 1979 seem to indicate that intensive religions expericnces are rebuvely common in the westem world, there should be ample opporthiry sol catrying this out.

\section{References}

Areti, S. 1974. Interpretation of schizophenia. New York.

- 1976. Creativity, the movic symhesis. New York.

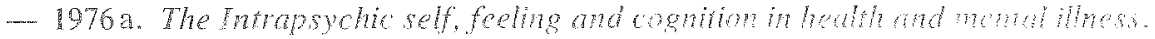
New York.

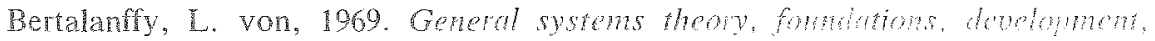
applications. New Kork.

Buber, M. 1961. Between man and man. London.

Clark, W. H. 1969. The prychology of religion. Toronto.

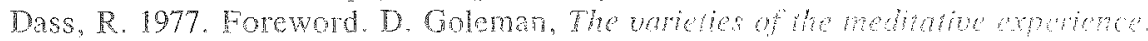
New York.

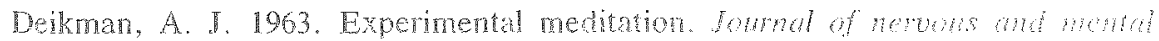
disease $136,329-343$.

- 1966 a. Implications of experimentally induced contemplative moturem 7 m. nal of nervous and mental discase $142,101 \ldots 116$.

- 19666. Deautomatization and the mystic experinge. Psychory 29,334338

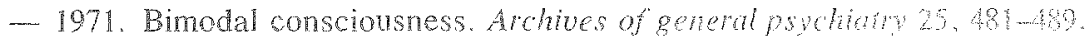

- 1976. Bimodal consciousness and the mystic experbence, Symmim at consciousness, ed. by $\mathbb{P}$. Lee et al. $67-88$. New rork.

Ellwood, R. S., Ir. 1980. Mysticism and relipion. Englewoon chits.

Freud, S. 1962. Dromtydning. Stockholm.

Geels, A. 1980. Mystkem Hialmar Elstrom (1885-1962). Hund

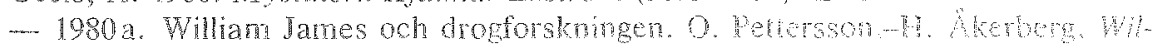
liom James dio och nu 129-151. Lund.

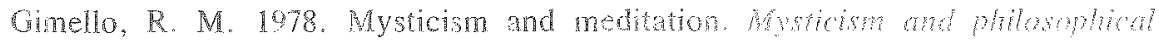
andysis, ed. by S. T. Katz, 170-199. Lonkon.

Goleman, D. 1975. The Buddha on methation and stres of conscionsness. Trus personal Psychologies, ed. by C. T. Tart, 203 230. London.

- 1981. Rorgetuhess of things past psychology toloy, orober 1720.

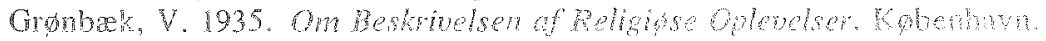

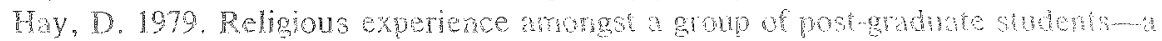

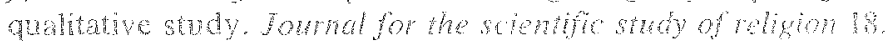


Hay. D.-Morsy. A. 197\% Reports of ecstaic paranomal, or religous experience in Great Wratin and Une Unted States-a comparison of trends. Jownal for the

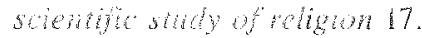

Wrat, T. 1978. Zen and the nind New Yonk.

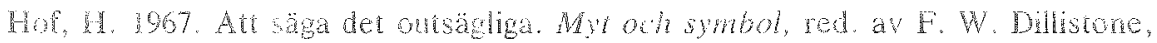
143-215. Swockholm.

- 1952. Scintlla Anmae, Land-Bonin.

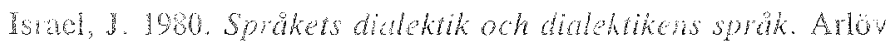

Janes. W. 1904. The varieties of retigions experience. London.

- 1956. Den wighön wefrenhen i dess skilda former. Stockholm.

Jethar, M. 1978. Ways of cognitive action. Iand.

- 1978 a. Helligent ellekentu? Iund.

- 1980. Den kreatra processen-pedagogiska implikanoner. Nordisk Psykologi, Vol, 32, 3, 266-275.

Kasamatsu, A.-Hirai, T. 1972. An elechoencepahlographic sidy on Zen meditation zazens. Alewd sates of consciousness, ed by C. T. Tart, $501-514$. New Yonk.

Korzyoski, A. 1951. The rote of Iangage in the perceptual processes. Percetion, wh approde to personaliy, ed. by R. R. Blake and G. V. Ramsey, 170-205. New York.

Kragh, U, Snith, G. 197n. Perepigeneric analysis. Lund.

Kagh, U.-Sinth, G.J.W. 1974. Forming new patcris of expentence, a classical problen viewed within a percept-genetic model. Psychological research bulletin $14,6$.

Kris, E. 1950. On preconscious montal processes. Psychoanalytic quarterly $19,542$. (Rewrinted in Rris 1952).

- 1952. Frychoanaly exploratons in art. New York.

Kubie, L. S. 1958. Nemotic distortion of the creative process Lawrence.

Lunger, 3.-Gugaman, S. 1978. Die Enrwicklungstheorien von Heinz Wener and Jean Plagê. W. Steiner, Die Psychologie des 20. Jahrhoderts, 8, Piaget und die Folgen, 568-583. Zurich.

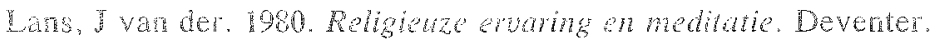

Laski, M. 1961. Erstasy, a study of some secular und religionts expentances. London.

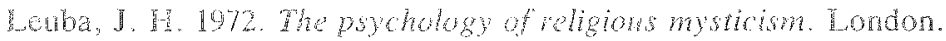

Maslow, A. H. 1973. Religion, wahes, and peakexperiencs. New Yotk.

Moore, G. 197\%. Recent sudies of mysticism, a critical survey. Jommat of relighon and relighon 3, 146-156.

- 1978. Mystcal experience, mystical doctrive, mystical technique. Mysticisn and phinopheal analysis, ed. by S. T. Katz, 101-131. London.

Nass, A. 1980 . Whenskepsilosofi. Oslo.

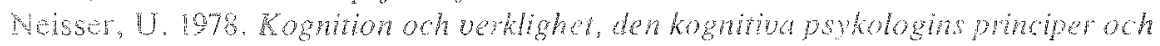
konskuenses. Suckholm.

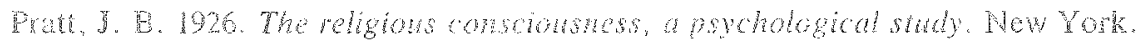

Tothenbers, A. 1979. The emering godiess. Chicago.

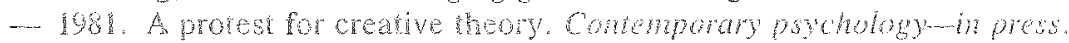

Euth, J.E. 1980. Creativity as a cognthe constuct; the affects of age, sex and tostug putice. Urpubl duct. diss. Univ of Southem Califormat.

Schachel, E. 1959. Aetamompars. New York. 
Scharfstein, B.-A. 1973. Mystical experience. Oxford.

Smart, N. 1962. Mystical experience. Sophia 1, 1, 19-26.

- 1966. Interpretation and mystical experience. Religious studies 1, 75-85.

Smith, G. J. W. 1981. Creation and reconstruction. Psychoanalysis and contemporary thought-in press.

Smith, G. J. W.-Danielsson, A. 1979. The influence of anxiety on the urge for aesthetic creation. Psychological Research Bulletin, 19, 3/4.

Smith, G. J. W.-Westerlundh, B. 1980. Perceptgenesis, a process perspective on perception-personality. Review of Personality and Social Psychology, ed. by L. Wheeler, 94-124. Beverly Hills.

Staal, F. 1975. Exploring mysticism. London.

Stace, W. T. 1960. Mysticism and philosophy. London.

Suler, J. R. 1980. Primary process thinking and creativity. Psychological bulletin $88,1,144-165$.

Sundén, H. 1970. Meditation and perception. Mysticism. ed. by S. S. Hartman and C.-M. Edsman, 34-46. (Scripta Instituti Donneriani Aboensis 5.) Stockholm.

Söderblom, N. 1975. Till mystikens belysning, Uppenbarelsereligion; Tre livsformer, Två skrifter med förnyad aktualitet. Lund.

Underhill, E. 1926. Mysticism. London.

- 1960. The essentials of mysticism and other essays. New York.

Wallas, G. 1926. The Art of thought. New York.

Werner, H. 1957. The concept of development from a comparative and organismic point of view. The Concept of Development, ed. by D. B. Harris, 125-148. Minneapolis.

- 1948. Comparative psychology of mental development. New York.

Westerlundh, B. 1976. Perceptgenes. Psykologisk uppslagsbok, utg. av J. Johannesson, 313-314. Stockholm.

Zaehner, R. C. 1967. Mysticism sacred and profane. London. 